Deleveraging in a highly indebted property market:

Who does it and are there implications for household consumption?

Yvonne McCarthy and Kieran McQuinn 


\title{
Deleveraging in a highly indebted property market: Who does it and are there implications for household consumption?
}

\author{
Yvonne McCarthy \& Kieran McQuinn*
}

March 2014

\begin{abstract}
A distinguishing feature of the period preceding the 2007/08 financial crisis was the sizeable increase in private sector debt observed across many countries. A key component of household liabilities is mortgage debt and with many countries experiencing persistent increases in house prices from the mid-1990s onwards, a marked increase in this aspect of household leverage was observed. While aggregate statistics across countries confirm reductions in personal debt levels in recent years, relatively few sources of micro data are available to examine the nature of the deleveraging process at the household level. In this paper, using a unique combination of regulatory and survey data, we examine deleveraging amongst a representative sample of mortgaged Irish households. In particular, we examine the characteristics of households presently reducing their debt levels and empirically assess whether the subsequent balance sheet adjustments have implications for key economic decisions. Our analysis suggests that, typically, it is those households who can deleverage, who do, and furthermore the decision to deleverage has negative implications for household consumption.
\end{abstract}

JEL classification: D12, D14, E21.

Keywords: Deleveraging, Debt, House Prices, Consumption.

*E-mail: yvonne.mccarthy@centralbank.ie and kieran.mcquinn@centralbank.ie. Address: Financial Stability Department, Central Bank of Ireland, PO Box 11517, Spencer Dock, North Wall Quay, Dublin 1, Ireland. Tel: +35312246000 . The views expressed in this paper are those of the authors and do not necessarily reflect those of the Central Bank of Ireland or the European Central Bank. We would like to acknowledge the comments of Gerard O'Reilly and those who participated in a Central Bank seminar. Any remaining errors are the responsibility of the authors. 


\section{Non-technical summary}

In this paper we use two unique sources of data to examine the extent to which Irish mortgaged households are deleveraging. In particular, we focus on whether households are making overpayments to clear their debt more quickly or using savings to supplement their payments. We also examine if the decision to deleverage has implications for household consumption.

The Irish market is of specific interest in this regard owing to the rapid increase in household indebtedness prior to 2007 vis-à-vis other western economies. A significant element of this increase in indebtedness is attributable to the Irish property boom of 1995 to 2007, when the growth in both Irish house prices and activity levels was amongst the largest across the OECD.

Our results suggest that it is older, more affluent Irish households, which are deleveraging. In particular, the probability of deleveraging is highest among those households with higher levels of income, with older or retired / inactive heads of household, and among those households where the head is relatively well educated. Furthermore, in a result that reinforces the importance of affordability in any deleveraging decision, we find that households are likely to reduce their deleveraging if they expect a deterioration in future financial conditions. Finally, we find that the decision to deleverage has negative implications for consumption patterns. 


\section{Introduction}

A distinguishing feature of the period preceding the 2007/08 financial crisis was the sizeable increase in private sector debt observed across many countries. From the early 1990s the combination of greater credit provision amongst international financial systems and favourable macroeconomic conditions resulted in many household sectors becoming increasingly indebted. While non-mortgage finance grew strongly over this period, due, in the main, to the greater availability and use of credit cards, mortgage debt, in particular, witnessed a sizeable increase. The sustained rise in both house prices and activity levels experienced across much of the OECD resulted in an escalation in household leverage. Given the subsequent downturn in economic activity due to the financial crisis of 2007/08 and the associated correction in house prices experienced in some of these markets, aggregate statistics suggest that many households are currently engaged in deleveraging, i.e. reducing their personal debt levels. Such a course of action can, potentially, have serious implications for key economic variables; when households seek to pay down their debts, a reduction in consumption and/or an increase in savings levels is very often observed. At a time when economic growth rates across countries are still struggling to recover from the financial crisis, this could act as a further drag on economic activity.

While aggregate information across countries is indicative of a general reduction in debt levels, there is, however, a relative paucity of information at the micro-household level. Given the likely heterogeneous nature of households' balance sheets and both their capability and inclination to deleverage, obtaining an understanding of this issue at a micro level is highly advantageous. Certain key questions can be addressed with micro data such as what causes household debt levels to change and what the nature of the relationship between debt levels and consumption is? Typically, in understanding the implications of adverse financial shocks, it is assumed that changes in household debt very often occur endogenously due to wealth effects, i.e. if housing wealth declines, households may spend less and save more thereby resulting in a decline in borrowing to fund such spending. Therefore, debt levels change due to wealth effects.

However, there are a number of reasons why households may target or pay attention to the level of debt itself, independent of the wealth effect. Households may, for example, have a certain level of leverage which they aim to maintain. In property markets, such as the US and Irish case, where the persistent fall in house prices between 2007 and 2012 will have caused increased leverage levels, households may reduce their spending and increase their debt repayments in order to re-establish their desired debt levels. Secondly, financial institutions are typically more reluctant to lend to highly indebted households, thereby, potentially restricting a source of their consumption finance. House price falls are often associated with lower debt and, as Mian and Sufi (2011) illustrate, reduce the ability of households to engage in home-equity-based borrowing. Therefore, debt levels themselves may have a direct impact on consumption behaviour. 
Understanding the specific role played by debt in this manner is very important as it has pressing implications for the way in which economists typically assess consumption behaviour. As Dynan (2012a) has noted, the empirical aggregate consumption function most often used by policy makers does not, generally, include debt or leverage as an explanatory variable. Balance sheet issues are mainly incorporated through an expression for aggregate net worth. However, if deleveraging itself has implications for consumption, then omitting debt levels from standard consumption frameworks, especially at the current juncture, could be quite misleading. Recent micro-based studies in the United States (Dynan (2012b) and Mian et al (2013)) suggest that high debt levels have implications for consumption. Dynan (2012b), in particular, having controlled for wealth levels, concludes that elevated leverage levels appear to be associated with weak consumption growth.

In this paper, using a unique combination of regulatory and survey data, we assess the deleveraging decision amongst a representative sample of mortgaged Irish households. In particular, we examine the impact of various socio-economic and demographic variables on the deleveraging decision before assessing the effect of deleveraging on household consumption. To this aim, we use data from two unique micro-data sources. The first is mortgage loan-level data that is gathered on a regular basis for the three main Irish financial institutions. ${ }^{1}$ This dataset includes administrative information on mortgage loans such as outstanding balances, repayment behaviour and collateral values. This dataset is supplemented by information from a representative household survey conducted in 2012/2013 on the mortgage books of the same institutions. Along with details such as the current consumption, income, expectations and labour market status of these households, respondents were also asked questions that capture deleveraging behaviour.

These combined datasets offer a number of advantages over existing studies. In particular, unlike the work of Dynan (2012b), we are in a position to directly observe deleveraging at the household level, rather than relying on household leverage ratios to proxy for such behaviour. Given the specific information we have on house prices, we are also able to control for housing wealth effects. Dynan (2012b) illustrates the importance of such a control and highlights the omission of such wealth effects from previous studies.

In terms of household deleveraging, the Irish market is of specific interest owing to the rapid increase in household indebtedness prior to 2007 vis-à-vis other western economies. In the three year period 2005 to 2007, Cussen et al (2012) estimate that, out of a sample of 24 European countries, Irish household debt had, as a percentage of disposable income, increased by more than any other country. By 2007, for example, the Irish household leverage ratio was 200 per cent - the fourth highest amongst the countries concerned.

Our results suggest that it is older, more affluent Irish households, which are deleveraging. In particular, the probability of deleveraging is highest among those households with higher levels of income, with

\footnotetext{
${ }^{1}$ These institutions account for around 70 percent of the outstanding stock of mortgages in Ireland.
} 
older or retired / inactive heads of household, and among those households where the head is relatively well educated. Furthermore, in a result that reinforces the importance of affordability in any deleveraging decision, we find that households are likely to reduce their deleveraging if they expect a deterioration in future financial conditions. Finally, we find that the decision to deleverage has negative implications for consumption patterns.

Our results have an added policy relevance given the present distressed nature of the Irish mortgage market. Most of the increase in Irish household indebtedness was due to developments in the residential property market. Irish house price growth was, between 1995 and 2007, the largest across the OECD, while activity levels were also considerably elevated with 340,000 new mortgages alone being approved between 2004 and 2006. ${ }^{2}$ However, since 2007, the near 50 per cent fall in Irish house prices coupled with a sharp increase in unemployment has given rise to a considerable negative equity and mortgage arrears problem. ${ }^{3}$ Owing to the scale of difficulties, a number of Government initiatives have sought to address the issue. ${ }^{4}$ Clearly, a greater understanding of households' capacity to redress their indebtedness positions is informative in tailoring effective and efficient policy responses to these difficulties.

The rest of this paper is structured as follows; in the next section we provide an overview of aggregate developments in Irish household indebtedness and deleveraging in recent years. In Section 3 we describe the datasets used and present a descriptive overview of the sample of interest. Section 4 examines the role of household socio-economic and demographic characteristics in the deleveraging decision. In Section 5 we explore the impact of deleveraging on household consumption while a final section discusses the policy implications from the results and offers some concluding comments.

\section{Indebtedness amongst Irish households}

Much of the increase in indebtedness experienced by Irish households is attributable to the Irish property boom of 1995 to 2007. Over this period, the growth in both Irish house prices and activity levels was amongst the largest across the OECD. The emergence of the so-called Celtic Tiger in the mid-1990s saw the size of the economy double over the period 1995 to 2005 with the total number of people employed in the economy increasing by almost 50 per cent. Figure 1 plots key Irish macroeconomic data from 1985 to 2012. From the mid-1990s onwards, the sizeable increases in income combined with an accommodative monetary policy lead to sustained rises in affordability amongst a young prospective home-owning population. Inevitably, as can be seen from Figure 2, house prices began to rise sharply.

\footnotetext{
${ }^{2}$ The national stock of mortgages at the time was close to 800,000 units.

${ }^{3}$ As of end-September 2013 , there were 99,189 (12.9 per cent of the total stock) private residential mortgage accounts for principal dwelling houses (PDH) in arrears of over 90 days, while internal Central Bank estimates suggest that up to 400,000 mortgages (52 per cent of the total) were in negative equity at the same time.

${ }^{4}$ See Kelly et al (2012) for more on this.
} 
An additional cause of increased housing market activity was the greater provision of mortgage credit in the Irish economy. Since the mid-1980s, the domestic credit market underwent a sustained period of financial liberalisation involving the removal of both credit and interest-rate controls. ${ }^{5}$ While all of these changes culminated in significant credit expansion by Irish financial institutions, the most profound development in the provision of credit was the increased ability of Irish banks, from the early-2000s, to attract deposits from non-residents. Figure 3 details the source of funding for Irish resident credit institutions from 2001 onwards along with the difference between credit extended and the deposit base in the Irish financial system. The rapid increase in debt securities issued by Irish credit institutions post-2003 resulted in a marked expansion in total lending to the economy.

Therefore, the combined effect of financial liberalisation, in an Irish context, was to increase the elasticity of the supply of credit to the household sector. The effect can be observed from Figure 4, where a simple stylised example of the supply and demand for credit is presented. With the advent of international, wholesale funding, a flatter supply curve for credit existed post-2003 in the Irish market. Credit institutions could now increase the amount lent to the household sector with little upward pressure on interest rates. Consequently, this increase in supply resulted in elevated levels of debt (from equilibrium point $A$ to $C$ ). The flatter supply curve also ensured that a given rise in demand lead to a larger surge in debt (moving from $C$ to $D$, rather than $A$ to $B$ ). Previously, such a change in demand would have caused a significant increase in mortgage interest rates which, in turn, could have acted as a brake on affordability and, hence, household demand.

The resulting overall trend in Irish households' liabilities can be observed from Figure 5. Debt levels continued to rise, albeit at a slower pace, after the peak had been reached in the property market in 2007, however, from the end of 2008, liabilities started to decline. Cussen and Phelan (2010) highlight the corresponding increase in household leverage which they measure using (i) a ratio of total liabilities to disposable income and (ii) a ratio of total liabilities to total assets (financial and nonfinancial). These measures are replicated in Figure 6 and clearly illustrate the increasing financial pressure experienced by Irish households. The increase in the ratio of liabilities to income is arguably a more accurate measure as the alternative (liabilities to assets) can be ameliorated by the increasing house and equity prices experienced prior to 2007.

In principle, the decision to deleverage is achieved by paying off debts and/or writing down existing loans. In Figure 7 the quarter-on-quarter change in Irish household liabilities is presented. In the aftermath of the financial crisis, the rate of increase in liabilities slowed significantly, while the increase in deleveraging is apparent from early 2009. As can be seen, in an aggregate sense, this has occurred through a combination of paying off debts (transactions) and writing-down of loans (revaluations).

\footnotetext{
${ }^{5}$ See McCarthy and McQuinn (2013a) for a detailed discussion of this.
} 


\section{Overview of data}

While observing the aggregate trends in deleveraging is informative, from a policy perspective, micro household level information is clearly optimal. To that end, two sources of data are used in this paper. The first is a mortgage loan-level dataset collected by the Central Bank of Ireland as part of a prudential capital assessment review exercise of the Irish banking sector. Covering three Irish residential mortgage banks, which account for approximately 70 per cent of the loans issued in the Irish market, the dataset includes a snapshot of the entire residential mortgage book at June 2012. The loan level dataset incorporates a broad array of information for each loan, including borrower and mortgage details from the point of loan origination, current information on the performance of the loan and information on the value of the property on which the mortgage is secured. Table 10 in the Appendix provides an overview of the contents of the dataset.

Complementing this information is a survey of the same residential loan book primarily designed to capture the current economic circumstances of Irish mortgagees. ${ }^{6}$ The survey, which was administered to over 2,000 households, all of whom are included in the loan-level dataset, was conducted over the period May 2012 to February 2013 and includes 97 questions asked of participants. ${ }^{7}$ While the survey mainly asks questions concerning relevant economic considerations such as consumption, income and employment status, participants are also asked about deleveraging activities.

To capture household deleveraging, respondents were first asked if they were concerned about their current level of debt; over 55 per cent of respondents reported that they were either very concerned or fairly concerned about their debt levels. ${ }^{8}$ These respondents were then presented with the following question:

\section{What actions, if any, are you taking to deal with your concerns about your current level of debt?}

Respondents could answer from a list of options (eg taking no action, cutting back expenditure, etc.), or they could provide an answer in a free text field. We create a dummy variable to capture deleveraging, which equals one if a respondent reported, firstly, that they were worried about their debt and, secondly, that they were making overpayments to clear their debt more quickly or they were using savings to supplement their payments. We compare these individuals to those who reported that they were worried about their debt but who were not engaged in these deleveraging activities as a means of dealing with their debt concerns. ${ }^{9}$ Of the sample who were concerned with their debt, about 12 per cent were involved in deleveraging activities.

\footnotetext{
${ }^{6}$ This survey was commissioned by the Central Bank of Ireland and was carried out by Ipsos MRBI on behalf of the bank. Further details on the survey are provided in the Appendix.

${ }^{7}$ Of these 2,000 households, 88 per cent gave permission for their survey responses to be linked to their loan-level data.

${ }^{8}$ Of course households who are not concerned with their debt levels may also decide to deleverage.

${ }^{9}$ Our definition of deleveraging can be regarded as "explicit" deleveraging where households pay down debts in excess of required repayments. Deleveraging also occurs "implicitly" through the servicing of debt repayments in the absence of any additional debt being incurred.
} 
Table 1 provides an overview of the characteristics of the sample used in this study, according to deleveraging status. ${ }^{10}$ In both the deleveraging and non-deleveraging groups, the largest portion of respondents is in the 35 to 44 year age group. The majority of respondents are married, employed and are relatively well educated, with about 40 per cent of respondents having a third level degree or higher. In terms of household composition, the average household in the sample comprises three persons (usually two adults and one child).

Comparing the deleveraging and non-deleveraging groups, the differences in demographic and labour market status do not appear stark. There are slightly older cohorts, more employed or inactive people, more highly educated people and slightly more widowed, divorced or separated people among the deleveraging group, but these differences are minor. ${ }^{11}$ The differences between the groups are more pronounced, however, when considering the financial information.

Average income appears higher among the deleveraging sample; median income in this case is $€ 65,000$ relative to $€ 55,000$ in the case of the non-deleveraging group. Average consumption is also higher for those who deleverage, their current house value is greater and, notably, a higher proportion of the deleveraging group report saving on a regular basis. Specifically, approximately 45 per cent of the deleveraging group saves regularly compared to 32 per cent of the non-deleveraging group. These results suggest that income and wealth may play a role in the deleveraging story. In the next section, we assess the importance of such factors in a multivariate setting.

\section{Empirical approach - who deleverages?}

To explore the deleveraging decision empirically, we specify the following cross-sectional, probit model, where the probability of deleveraging is a function of income and a series of household-specific controls:

$$
\operatorname{Prob}\left(y_{i}=1\right)=F\left(\beta\left(x_{i}\right)+\epsilon i\right) ; i=1,2, \ldots n
$$

Where $y_{i}$ is the dependent variable "Deleverage", $x$ comprises controls for the $i t h$ household's characteristics and financial information, $\beta$ is a set of parameters to be estimated and $\epsilon_{i}$ is the error term.

Table 2 provides a full overview of the independent variables used in the model. To control for household characteristics, we include variables denoting the gender, age, marital status, educational attainment and employment status of the main mortgage contributor. We also control for the number of people in the household, the household's mortgage leverage (captured by the current loan-to-value ratio) and the $m r t i$ or mortgage repayment-to-income ratio of the household. This latter variable, which was originally presented

\footnotetext{
${ }^{10}$ The sample at this stage is restricted to those individuals who reported that they were worried about their debt.

${ }^{11}$ The inactive group includes people who are retired, on home duties or students.
} 
in McCarthy and McQuinn (2011), is used as a household liquidity indicator and is particularly pertinent at a time when many Irish households are experiencing mortgage repayment difficulties.

\subsection{Baseline Results}

Table 3 presents the results of the initial estimation. A clear picture emerges as to the profile of Irish households that are deleveraging; those with higher levels of income, with a head of household who is retired or inactive and those households with a relatively well educated head, are the most likely to deleverage.

In Table 4 we repeat the previous regression, this time replacing the income variable with dummy variables capturing income quartiles. The omitted category "Income Quartile 1" captures the 25 per cent of the sample with the lowest income levels. The results suggest that it is those households with the highest income level that are most likely to deleverage with the coefficient on "Income Quartile 4" suggesting that those households at the upper end of the income distribution have an 8.5 per cent higher probability of deleveraging relative to those households at the lower end of the distribution.

As a further check on the results, we include one additional control in the regression to proxy for household wealth - a dummy variable for households who report that they have regular monthly savings. The results are shown in Table 5. In terms of household characteristics, the coefficients are much the same as in the earlier regressions; higher income households and those with highly educated or retired / inactive heads have a higher probability of deleveraging. The savings dummy is significant at a 10 per cent level and suggests that those households with regular monthly savings have a 4 per cent higher probability of deleveraging relative to those households with no regular savings. Thus far, therefore, the results suggest that it is those households with the means to deleverage who do. In the next section, we examine whether the recent distress in the mortgage market has implications for deleveraging.

\subsection{Mortgage market distress}

The Irish housing market has faced significant challenges in recent years, with Irish house prices falling by over 50 per cent from their peak in 2007. Given that a sizeable portion of the stock of outstanding mortgages was taken out at a time when house prices were at or close to their peak, the proportion of mortgaged properties in negative equity is likely to be substantial. Central Bank of Ireland estimates, based on earlier work by Duffy (2010), suggest that between 40 to 50 per cent of the total stock of Irish mortgages was, at end-2012, in negative equity. Given the significance of the problem, it is interesting to assess its importance for household deleveraging.

There are a number of reasons why one might expect households in negative equity to engage in deleveraging. Firstly, since high leverage ratios can have a negative impact on access to credit, households may be encouraged to deleverage to repair their equity position and to restore their credit access. Or 
households may not be comfortable being in negative equity, preferring instead to keep their leverage close to some target lower level. On the other hand, however, negative equity may negatively impact deleveraging; households may feel uncertain about future policies in respect to debt reduction and easing of negative equity, thereby preferring to 'wait-and-see' if some form of debt relief might be available. ${ }^{12}$ Of course, there is also the possibility that households may not be aware of their equity position, perhaps not knowing exactly what their mortgage debt or current house price is, so that negative equity may have no impact at all on the deleveraging decision. In this context, McCarthy and McQuinn (forthcoming) provide evidence that mortgage holders have difficulty in recalling details of their mortgage debt.

In Table 6 we include a dummy variable capturing households in negative equity in the deleveraging regression. The coefficient on the negative equity variable is negative but it is not significant, suggesting that negative equity does not have an impact on the deleveraging behaviour among our sample of mortgaged Irish households. The importance of the remaining variables in the model is not altered (from a statistical significance perspective) relative to the earlier findings.

One further issue worth exploring at this stage, is whether credit constraints impact the deleveraging decision. Given the well documented problems in the Irish banking sector, banks are arguably more reluctant to lend to highly leveraged borrowers. As mentioned above, borrowers who are credit constrained might prefer to reduce their leverage to restore credit access. We explicitly test this hypothesis by using information on recent credit applications in our survey data. Specifically, respondents are asked: (1) if they applied for credit in the past three years; (2) about the outcome of any such applications; and (3) if they considered applying for credit but, fearing rejection, decided not to apply. This latter question could capture cases where past credit applications have been rejected.

We create a dummy variable, credit constrained, that captures individuals who either had a credit application rejected in the past three years or who did not apply for credit because they feared rejection, and include this as an additional control in the model. ${ }^{13}$ The results, shown in Table 7, reveal an insignificant coefficient on the credit constraints variable, suggesting that credit constraints are not a significant reason for deleveraging in the Irish market.

\subsection{Future income uncertainty}

A key finding to emerge, therefore, is that it is those households with the means to deleverage that do. In this context, and given the significant changes experienced in key economic variables such as incomes and unemployment rates in Ireland in recent years, it is interesting to consider the effect of increased financial uncertainty on the deleveraging decision. To address this question, we follow Manski (2004), Christelis et

\footnotetext{
${ }^{12}$ Certain recent legal reforms in Ireland, such as the introduction of new personal insolvency legislation, have lead some commentators to suggest that significant debt relief for distressed mortgagees may be inevitable - see FitchRatings "Debt forgiveness a potential concern for Irish RMBS" for example.

${ }^{13} \mathrm{Almost} 14$ per cent of the sample falls into this group.
} 
al (2011) and McCarthy and McQuinn (2013b) who use households' subjective expectations as a means of characterising their attitudes to the distribution of future shocks. In particular, we use a specific question to gauge households' subjective expectations for future financial developments.

Households are asked whether they expect to be better off, worse off or the same in terms of their financial circumstances over the next year. We generate a dummy variable that captures those individuals who expect to be worse off in a year, relative to those who expect their position to improve or stay the same, and include this as an additional control in the regression. The results, reported in Table 8, suggest that an expected deterioration in future financial circumstances leads to a reduction in deleveraging. In particular, individuals who expect to be worse off in the future have a 4 per cent lower probability of deleveraging, relative to people who either expect no change in their circumstances or to be better off in the future. This result is compatible with our earlier finding that affordability is a key factor in the deleveraging decision.

\subsection{Summary}

In summary, the analysis, thus far, has focussed on identifying the factors associated with the deleveraging decision. The results suggest that it is those households with the means to deleverage that do; households with retired / inactive heads, higher income and regular savings tend to deleverage more often than other types of households. Interestingly, recent distress in the mortgage market such as negative equity and credit constraints do not seem important. On the other hand, future expectations about a household's financial circumstances have a role to play in the deleveraging decision; those households that expect to be worse off in the future are less likely to deleverage relative to those households who expect either to be better off or to experience no change in their financial position. This provides further support for the finding that affordability plays a key role in deleveraging in an Irish context. As a next step in the analysis, we examine the implications of the deleveraging decision for household consumption.

\section{Deleveraging and household consumption}

As noted by Cooper and Dynan (2013), the theoretical case for a specific role for household debt in determining consumption is not readily apparent. In many standard models of consumption, debt does not exert an independent influence on consumption. In such cases, where households, say, experience a negative house price shock, debt levels contract, exclusively, in an endogenous fashion; in response to the ensuing negative wealth effect, households reduce their consumption and borrow less accordingly. Therefore, debt levels decline.

However, there are a number of reasons to believe that households may respond to or target the level of debt itself, independent of the wealth effect and this, in turn, could affect consumption. Households, may, 
for example, have a target level of debt relative to either household income or assets. In the latter case, with a significant fall in house prices, they may wish to redress the ratio by reducing debt levels. Similarly, debt levels play an important role in accessing credit. Financial institutions are, typically, reticent to lend to significantly indebted households. In terms of the life cycle hypothesis, this may be particularly relevant where households perceive their current income to be below the permanent level and thus, may wish to borrow to smooth consumption levels. Heightened levels of debt would clearly impede access to finance.

To date, micro level analysis of the relationship between debt and consumption at a household level is at a relatively nascent stage. Indeed, Cooper and Dynan (2013) describe household level empirical research in this area as being "limited". A number of US based studies such as Dynan (2012b) and Cooper (2012) find that high levels of debt have a negative impact on consumption after controlling for income and net worth, while Dynan and Edelberg (2013) demonstrate that high debt households were more likely to reduce their consumption in 2009 after controlling for other determinants of spending.

To assess the impact of deleveraging on consumption, we use a survey question that asks respondents how their consumption changed relative to a year earlier (increased / decreased / no change) and by how much it changed. A continuous variable is created capturing such information and this is used as the dependent variable. ${ }^{14}$ As controls, we employ the same binary independent variables as before. In addition, to control for changes in housing wealth, we include a continuous variable capturing the change in housing equity for each household between June-2011 and June-2012..$^{15}$ In terms of income, our survey does not capture numerical changes. Rather respondents are asked only about how their income has changed in a qualitative sense (increased / decreased / no change) over the previous year. We generate a dummy variable capturing cases where households registered a fall in their income over the past year, and include this as an additional control in the regression. The results are shown in Table 9. ${ }^{16}$

Turning first to household characteristics, the education level of the head of the household has an important impact on consumption changes. More highly educated heads tended to register an increase in consumption levels over the year; heads with a medium education level saw their consumption rise by $€ 91$ relative to households where the head has a low level of education, while those with a high level of education increased their consumption by $€ 87$. Income developments also have an important impact on consumption developments among the sample. Relative to households that registered an increase or no change in their income over the year, households that saw a reduction in income tended to record lower consumption levels. Finally, larger households (as captured by "HH size") tended to increase their consumption levels over the year.

In incorporating deleveraging into the consumption regression, we use the dummy variable outlined in section 2. Therefore, in using the observed decision to reduce debt, rather than levels of leverage, our

\footnotetext{
${ }^{14}$ Full details of the questions employed and the distribution of changes are available in the Appendix.

${ }^{15}$ See the Appendix for further details.

${ }^{16}$ We also tried including the level of income, however, this was not significant in the regression.
} 
estimate of deleveraging is more precise than that used in other micro-level studies. The coefficient on our deleveraging variable suggests that households engaged in deleveraging reduced their consumption by an average of about $€ 68$ in the year. Thus, controlling for housing wealth, once households decide to deleverage, consumption is adversely affected.

\section{Conclusions}

In assessing aggregate trends in total household debt and consumption levels, many commentators have speculated as to the implications of debt reduction amongst households on economic activity. Given a unique combination of survey and regulatory data, in this paper we directly observe deleveraging amongst a representative sample of mortgaged Irish households. Consequently, we are in a position to both observe the characteristics of those households which are deleveraging and to examine the implications for household consumption. Our key finding that household consumption is affected by changing debt levels is quite significant at a time when a debate exists as to whether debt levels should be even considered in standard consumption frameworks. Our results benefit from a relatively precise definition of deleveraging, while controlling for household-specific wealth effects.

Given that our results suggest that it is a relatively affluent cohort of the mortgaged population who are more likely to engage in deleveraging, a number of policy implications arise. Firstly, it suggests that certain less well-off sections of the mortgaged population are likely to remain significantly indebted while they are unable to address their leveraged position. This conclusion may be of interest in the context of possible debt resolution strategies for the sizeable negative equity problem confronting the Irish mortgage market.

The results also suggest that as household income levels begin to recover, the knock on implications for consumer demand may not be as significant as would be expected. More generally, the importance of debt levels themselves for consumption behaviour, as indicated by the results presented here, illustrate an important linkage between financial sector developments and the real economy. 


\section{References}

[1] Carroll C.D. and A. Samwick (1997), "Buffer stock saving and the life-cycle permanent income hypothesis," The Quarterly Journal of Economics, 112, pp.1-55.

[2] Cussen M., O'Leary B. and D. Smith (2012), "The impact of the financial turmoil on households: A cross country comparison", Irish Central Bank Quarterly Bulletin Article 02, April, pp. 78 - 98.

[3] Cussen M. and G. Phelan (2010), "Irish households: Assessing the impact of the economics crisis", Irish Central Bank Quarterly Bulletin Article 04, October, pp. 62 - 76.

[4] Campbell J.Y. and J.F. Cocco (2007), "How do house prices affect consumption? Evidence from micro data," Journal of Monetary Economics, 54, pp.591-621.

[5] Christelis D. Georgarakos D. and T. Jappelli (2011), Wealth shocks, unemployment shocks and consumption in the wake of the great recession, Centre for Studies in Economics and Finance (CSEF) Working paper no. 279.

[6] Cooper D. and K. Dynan (2013), Wealth shocks and macroeconomic dynamics, Federal Reserve of Boston Public Policy Discussion Paper Series No. 13-4.

[7] Duffy, D. (2010). "Negative equity in the Irish housing market" The Economic and Social Review, 41, No. 1, 109-132.

[8] Dynan K. (2012a), What's been weighing on consumption? An overview of the recent experiences of different types of households, prepared for Federal Reserve Board Academic Consultants meeting on "Heterogeneity and aggregate consumption". Available at http://www.brookings.edu/research/papers/2012/05/household_heterogeneity_dynan

[9] Dynan K. (2012b), "Is a household debt overhang holding back consumption?", Brookings Papers on Economic Activity, Spring 2012.

[10] Gourinchas P. and J.A. Parker (2002), "Consumption over the life cycle," Econometrica, Vol. 70, No. 1, pp.47-89.

[11] Kelly R., McCarthy Y. and K. McQuinn (2012), "Impairment and negative equity in the Irish mortgage market," Journal of Housing Economics, Volume 21, pp. 256-268.

[12] Manski, C.F. (2004), “Measuring expectations,” Econometrica, 72, pp. 1329-76.

[13] McCarthy Y. and K. McQuinn (2011), "How are Irish households coping with their mortgage repayments? Information from the Survey on Income and Living Conditions", Economic and Social Review, Vol 42(1), pp.71-94.

[14] McCarthy Y. and K. McQuinn (2013a), Credit conditions in a boom and bust property market, Central Bank of Ireland Research Technical Paper 8/RT/13.

[15] McCarthy Y. and K. McQuinn (2013b), Price expectations, distressed mortgage markets and the housing wealth effect, Central Bank of Ireland Research Technical Paper 6/RT/13.

[16] McCarthy Y. and K. McQuinn (forthcoming), Attenuation bias, recall error and housing wealth effects, Central Bank of Ireland Research Technical Paper.

[17] Mian A. and A. Sufi (2011), "House prices, home equity-based borrowing and the US household leverage crisis". American Economic Review, 101, August pp. 2132-2156.

[18] Mian A., Kamalesh R. and A. Sufi (2013), "Household balance sheets, consumption and the economic slump". The Quarterly Journal of Economics, Published online: July 25. 


\section{A Creation of Variables from Loan-Level Dataset}

The analysis in this paper relies, in part, on variables that are generated from the loan-level data (described previously). Here we detail precisely how these variables are calculated.

\section{A.1 Current house price}

The loan-level dataset includes the value of the house for which the original mortgage was taken out as well as the valuation date. The current house price $\left(P_{t}\right)$ is calculated as follows:

$$
P_{t}=P_{0} \times \frac{\bar{P}_{t}}{\bar{P}_{0}}
$$

where $P_{0}$ is the latest valuation of the property, and $\frac{\bar{P}_{t}}{\bar{P}_{0}}$ is the change in the average value of 'similar' properties between $t=0$ and $t=t$.

For loans originating from 2005 onwards, we use the CSO property price index to calculate the change in house prices over time. We match 'similar' properties on the basis of region (Dublin and non-Dublin) and type (house, apartment, other). For loans originating prior to 2005 we use the ptsb/ESRI house price index, which has a similar geographic breakdown as the CSO price index, but not a similar breakdown by property type. We therefore apply the ptsb/ESRI price index changes to all house-types.

\section{A.2 Equity or Current Loan-to-Value Ratio}

To capture housing equity for each property in the sample we need two pieces of information: the current value of the property (described above) and the loan outstanding on the property. In terms of the latter, we add up the current balance outstanding on all loans secured on the same property to derive a total property debt figure. The LTV ratio is then calculated as follows:

$$
L T V_{t}=\frac{D e b t_{t}}{P_{t}}
$$

Those households with an LTV ratio of greater than 100 are deemed to be in negative equity, while those with an LTV ratio of less than or equal to 100 are deemed to have positive equity in their property.

\section{B The survey of mortgage holders}

The survey used in the present study was conducted by Ipsos MRBI on behalf of the Central Bank of Ireland. The primary purpose of the survey was to collect up-to-date information on a mortgage holder's financial position, which could be appended to the mortgage loan level information held by the Central Bank for the three main Irish financial institutions (AIB, BOI and ILP). The survey was designed to be representative of the loan books of the three main institutions along five dimensions: lender type, borrower type, interest rate type, arrears and county of residence.

A two-stage sampling approach was used for the selection of cases for interview. In the first stage, representative clusters were formed from the loan-level data. In the second stage, clusters were randomly selected for interview. The total sample size achieved was 2,086 households, while the linked sample (those cases that permitted for their survey information to be linked back to their loan-level data at the Central Bank of Ireland) accounted for 88 per cent of this. The survey included questions in the following categories:

1. Mortgage background, including questions on the contributors to the mortgage repayment, the educational and employment characteristics of such contributors and details of unemployment where relevant.

2. Income and finances, including detailed questions on household income, recent income changes, details on household expenditures and questions on repayment difficulties where relevant.

3. Buy-to-lets and other financial holdings, details of institutions where borrowings and savings are held and questions on credit applications and rejections, and future expectations. 
4. The mortgage arrears resolutions process (MARP), including questions on participation in the MARP process and the degree and nature of contact with the mortgage lender.

\section{Change in Household Consumption}

As discussed in Section 5, to assess the impact of deleveraging on consumption, we use a question in our survey that asks respondents how their consumption changed relative to a year earlier (increased / decreased / no change) and by how much it changed. The precise questions used are as follows:

1. Would you say this (household expenditure on goods and services, excluding debt repayments) has increased, decreased or remained the same compared to this time last year?

2. By how much would you say this has increased/decreased?

Individuals could pick from a selection of banded responses for the second question, so we use the mid-point of each range to capture the consumption amount. Where an individual reports "no change" in the first question, we set the consumption change to zero. Where they report that their consumption increased, we use the reported amount from question 2, and where they say that it decreased, we multiply the reported amount by -1 . Figure A1 shows the distribution of responses among the sample.

\section{Change in Housing Equity}

To assess the impact of deleveraging on household consumption, we need to control for the change in a household's net worth position. We use the change in housing equity to proxy for this variable. Housing equity is defined as the difference between the household's property value at a point in time and the loan outstanding at that point in time.

To calculate the annual change in housing equity in June 2012, we need a measure of housing equity in both June 2012 and June 2011. The figure for June 2012 is easily calculated in our dataset. However, for June 2011 we only have information on the value of the property at that point while we do not know the balance outstanding on the mortgage secured on that property. The dataset does, however, include the balance outstanding in December 2010 as well as the balance outstanding in December 2011, so we proxy for the balance outstanding in June 2011 using the mid-point of these two values. We are then in a position to calculate the amount of housing equity available to each household in June 2011. Taking this from the amount of equity in June 2012, we generate an estimate of the change in housing equity for each household in our sample. 
Table 1: Demographic and economic characteristics of the sample, \% of respondents unless otherwise stated

\begin{tabular}{|c|c|c|c|}
\hline Variable & Group & $\begin{array}{c}\% \text { of Deleveraging } \\
\text { Sample }\end{array}$ & $\begin{array}{c}\% \text { of Non-Deleveraging } \\
\text { Sample }\end{array}$ \\
\hline \multirow[t]{5}{*}{ Age Group (years) } & $18-34$ & 12.6 & 15.1 \\
\hline & $35-44$ & 41.2 & 40.3 \\
\hline & $45-54$ & 27.7 & 30.4 \\
\hline & $55-64$ & 16.0 & 11.7 \\
\hline & $65+$ & 1.7 & 2.2 \\
\hline \multirow[t]{3}{*}{ Marital Status } & Married / Couple & 83.2 & 81.8 \\
\hline & Widowed/Separated & 11.8 & 6.7 \\
\hline & Single & 5.0 & 11.5 \\
\hline \multirow[t]{3}{*}{ Work Status } & Employed & 84.0 & 81.5 \\
\hline & Unemployed & 5.0 & 9.4 \\
\hline & Inactive & 10.9 & 8.9 \\
\hline \multirow[t]{3}{*}{ Education Status } & Low & 9.2 & 14.7 \\
\hline & Medium & 44.5 & 45.0 \\
\hline & High & 45.4 & 39.5 \\
\hline \multirow[t]{5}{*}{ Household Composition } & 1 Adult, 0 kids & 6.7 & 9.4 \\
\hline & 2 Adults, 0 kids & 13.5 & 14.6 \\
\hline & $3+$ Adults, 0 kids & 5.9 & 6.9 \\
\hline & 1+ Adults, with kids & 65.6 & 62.5 \\
\hline & Other & 8.4 & 6.2 \\
\hline \multirow[t]{4}{*}{ Median Financial Data $(€)$} & Income & 65,000 & 55,000 \\
\hline & Consumption & 21,000 & 15,300 \\
\hline & Current House Price & 191,717 & 180,381 \\
\hline & Mortgage Outstanding & 185,918 & 170,394 \\
\hline Negative Equity & $\%$ of Group & 44.0 & 46.8 \\
\hline Any Arrears & $\%$ of Group & 20.2 & 28.2 \\
\hline Saves on a Regular Basis & $\%$ of Group & 44.5 & 31.7 \\
\hline
\end{tabular}

Note: Where group totals do not equal $100 \%$, the residual is accounted for by "don't know" or "refused" responses. 
Table 2: Independent Variables

\begin{tabular}{|c|c|}
\hline Variable & Description \\
\hline male & Dummy variable indicating that the survey respondent is male. \\
\hline married & Dummy variable indicating that the survey respondent is married. \\
\hline HH size & $\begin{array}{l}\text { Continuous variable indicating the number of people in the } \\
\text { household. }\end{array}$ \\
\hline age $: 18-34$ & $\begin{array}{l}\text { Omitted category - captures survey respondents who are aged between } \\
18 \text { and } 34 \text { years. }\end{array}$ \\
\hline age $: 35-44$ & $\begin{array}{l}\text { Dummy variable indicating that the survey respondent is aged between } \\
35 \text { and } 44 \text { years. }\end{array}$ \\
\hline age $: 45-54$ & $\begin{array}{l}\text { Dummy variable indicating that the survey respondent is aged between } \\
45 \text { and } 54 \text { years. }\end{array}$ \\
\hline age $: 55-64$ & $\begin{array}{l}\text { Dummy variable indicating that the survey respondent is aged between } \\
55 \text { and } 64 \text { years. }\end{array}$ \\
\hline age $: 65+$ & $\begin{array}{l}\text { Dummy variable indicating that the survey respondent is aged } 65 \text { years } \\
\text { or more. }\end{array}$ \\
\hline$e d u-l o w$ & $\begin{array}{l}\text { Omitted category - captures survey respondents with a low level of } \\
\text { education (lower second level or less). }\end{array}$ \\
\hline$e d u-m e d$ & $\begin{array}{l}\text { Dummy variable indicating that the survey respondent has a medium level } \\
\text { of education (upper second level and non-degree). }\end{array}$ \\
\hline$e d u-h i g h$ & $\begin{array}{l}\text { Dummy variable indicating that the survey respondent has a high level of } \\
\text { education (third level degree or above). }\end{array}$ \\
\hline unemployed & Omitted category - captures respondents who are unemployed. \\
\hline employed & Dummy variable indicating that the survey respondent is employed. \\
\hline retired/inactive & $\begin{array}{l}\text { Dummy variable indicating that the survey respondent is retired or inactive } \\
\text { (student, stay at home parent, etc.). }\end{array}$ \\
\hline$y_{i}$ & Logged gross annual income for household i. \\
\hline Income Quartile 1 & $\begin{array}{l}\text { Omitted category - captures respondents in the bottom } 25 \text { per cent of the } \\
\text { income distribution. }\end{array}$ \\
\hline Income Quartile 2 & Dummy variable capturing respondents in the 2 nd income quartile. \\
\hline Income Quartile 3 & Dummy variable capturing respondents in the 3rd income quartile. \\
\hline Income Quartile 4 & $\begin{array}{l}\text { Dummy variable capturing respondents in the 4th income quartile. } \\
\text { distribution. }\end{array}$ \\
\hline mrti & Log of the mortgage-repayment-to-income ratio for household $\mathrm{i}$. \\
\hline savings & Dummy variable capturing households that save on a regular basis. \\
\hline Current LTV & Loan-to-value ratio for household i (at June 2012). \\
\hline fixed rate mortgage & Dummy variable indicating that the mortgage is a fixed rate mortgage. \\
\hline
\end{tabular}


Table 3: Probit model: dependent variable=deleverages

\begin{tabular}{|c|c|c|}
\hline Variable & Marginal Effect & Std. Error \\
\hline male & -0.013 & 0.023 \\
\hline married & -0.007 & 0.037 \\
\hline HH size & 0.012 & 0.011 \\
\hline age $: 35-44$ & 0.000 & 0.034 \\
\hline age $: 45-54$ & -0.010 & 0.036 \\
\hline age $: 55-64$ & 0.078 & 0.062 \\
\hline age $: 65+$ & -0.052 & 0.069 \\
\hline edu-med & 0.068 & 0.043 \\
\hline$e d u-h i g h$ & $0.082^{*}$ & 0.048 \\
\hline employed & 0.071 & 0.036 \\
\hline retired/inactive & $0.167^{* *}$ & 0.104 \\
\hline$y_{i}$ & $0.053^{\star *}$ & 0.025 \\
\hline mrti & 0.033 & 0.021 \\
\hline current ltv & -0.013 & 0.016 \\
\hline fixed rate mortgage & -0.011 & 0.035 \\
\hline $\mathrm{N}$ & \multicolumn{2}{|l|}{830} \\
\hline LR chi ${ }^{2}$ & \multicolumn{2}{|l|}{24.26} \\
\hline Prob $>\mathrm{Chi}^{2}$ & \multicolumn{2}{|c|}{0.0609} \\
\hline Pseudo $\mathrm{R}^{2}$ & \multicolumn{2}{|c|}{0.0397} \\
\hline
\end{tabular}

Note: ${ }^{* * *}$ Significant at 1 per cent level; ${ }^{* *}$ Significant at 5 per cent level; * Significant at 10 per cent level. Omitted categories for dummy variables are: age 18-34; low education and unemployed. 
Table 4: Probit model: dependent variable=deleverages, including income quartiles

\begin{tabular}{|c|c|c|}
\hline Variable & Marginal Effect & Std. Error \\
\hline male & -0.011 & 0.023 \\
\hline married & 0.001 & 0.036 \\
\hline HH size & 0.012 & 0.011 \\
\hline age $: 35-44$ & -0.001 & 0.034 \\
\hline age $: 45-54$ & -0.010 & 0.036 \\
\hline age $: 55-64$ & 0.080 & 0.063 \\
\hline age $: 65+$ & -0.055 & 0.066 \\
\hline$e d u-m e d$ & $0.077^{*}$ & 0.043 \\
\hline$e d u-h i g h$ & $0.088^{*}$ & 0.048 \\
\hline employed & $0.081^{*}$ & 0.034 \\
\hline retired/inactive & $0.176^{\star *}$ & 0.105 \\
\hline Income Quartile 2 & 0.010 & 0.034 \\
\hline Income Quartile 3 & 0.012 & 0.041 \\
\hline Income Quartile 4 & $0.085^{\star *}$ & 0.048 \\
\hline mrti & 0.025 & 0.020 \\
\hline current ltv & -0.010 & 0.016 \\
\hline fixed rate mortgage & -0.010 & 0.035 \\
\hline $\mathrm{N}$ & \multicolumn{2}{|l|}{830} \\
\hline LR chi $^{2}$ & \multicolumn{2}{|l|}{25.20} \\
\hline Prob $>$ chi $^{2}$ & \multicolumn{2}{|l|}{0.0904} \\
\hline Pseudo $\mathrm{R}^{2}$ & \multicolumn{2}{|l|}{0.0413} \\
\hline
\end{tabular}

Note: ${ }^{* *}$ Significant at 1 per cent level; ${ }^{* *}$ Significant at 5 per cent level; * Significant at 10 per cent level. Omitted categories for dummy variables are: age 18-34; low education; unemployed; and income quartile 1 (lowest income group). 
Table 5: Probit model: dependent variable=deleverages, including wealth indicators

\begin{tabular}{lcc}
\hline \hline Variable & Marginal Effect & Std. Error \\
\hline male & -0.011 & 0.023 \\
married & -0.012 & 0.038 \\
HH size & 0.014 & 0.011 \\
age $: 35-44$ & -0.001 & 0.034 \\
age $: 45-54$ & -0.010 & 0.036 \\
age $: 55-64$ & 0.088 & 0.064 \\
age $: 65+$ & -0.052 & 0.070 \\
edu - med & 0.061 & 0.043 \\
edu - high & $0.072^{*}$ & 0.048 \\
employed & 0.066 & 0.038 \\
retired/inactive & $0.157^{*}$ & 0.102 \\
$y_{i}$ & $0.047^{*}$ & 0.025 \\
mrti & 0.033 & 0.021 \\
current ltv & -0.012 & 0.016 \\
fixed rate mortgage & -0.014 & 0.034 \\
savings & $0.043^{*}$ & 0.026 \\
& \multicolumn{2}{c}{826} \\
\hline $\mathrm{N}$ LR chi ${ }^{2}$ & \multicolumn{2}{c}{0.0395} \\
Prob>chi & \multicolumn{2}{c}{0.0446} \\
Pseudo ${ }^{2}$ & \multicolumn{2}{c}{} \\
\hline \hline
\end{tabular}

Note: ${ }^{* * *}$ Significant at 1 per cent level; ${ }^{* *}$ Significant at 5 per cent level; ${ }^{*}$ Significant at 10 per cent level. Omitted categories for dummy variables are: age 18-34; low education; and unemployed. 
Table 6: Probit model: dependent variable=deleverages, including negative equity

\begin{tabular}{|c|c|c|}
\hline Variable & Marginal Effect & Std. Error \\
\hline male & -0.012 & 0.023 \\
\hline married & -0.011 & 0.037 \\
\hline HH size & 0.014 & 0.011 \\
\hline age $: 35-44$ & -0.005 & 0.034 \\
\hline age $: 45-54$ & -0.017 & 0.036 \\
\hline age $: 55-64$ & 0.081 & 0.063 \\
\hline age $: 65+$ & -0.056 & 0.066 \\
\hline$e d u-m e d$ & 0.061 & 0.043 \\
\hline$e d u-h i g h$ & 0.073 & 0.048 \\
\hline employed & 0.066 & 0.038 \\
\hline retired/inactive & $0.156^{*}$ & 0.103 \\
\hline$y_{i}$ & $0.048^{*}$ & 0.026 \\
\hline mrti & 0.033 & 0.022 \\
\hline current ltv & -0.002 & 0.020 \\
\hline fixed rate mortgage & -0.013 & 0.034 \\
\hline savings & $0.042^{*}$ & 0.026 \\
\hline negative equity & -0.028 & 0.030 \\
\hline $\mathrm{N}$ & \multicolumn{2}{|l|}{826} \\
\hline LR chi ${ }^{2}$ & \multicolumn{2}{|l|}{28.04} \\
\hline Prob $>$ chi $^{2}$ & \multicolumn{2}{|l|}{0.0445} \\
\hline Pseudo $\mathrm{R}^{2}$ & \multicolumn{2}{|l|}{0.0460} \\
\hline
\end{tabular}

Note: ${ }^{* \star *}$ Significant at 1 per cent level; ${ }^{* *}$ Significant at 5 per cent level; ${ }^{*}$ Significant at 10 per cent level. Omitted categories for dummy variables are: age 18-34; low education and unemployed. 
Table 7: Probit model: dependent variable=deleverages, including credit constraints

\begin{tabular}{|c|c|c|}
\hline Variable & Marginal Effect & Std. Error \\
\hline male & -0.012 & 0.023 \\
\hline married & -0.012 & 0.038 \\
\hline HH size & 0.014 & 0.011 \\
\hline age $: 35-44$ & -0.001 & 0.034 \\
\hline age $: 45-54$ & -0.009 & 0.036 \\
\hline age $: 55-64$ & 0.088 & 0.064 \\
\hline age $: 65+$ & -0.052 & 0.069 \\
\hline$e d u-m e d$ & 0.061 & 0.043 \\
\hline$e d u-h i g h$ & 0.073 & 0.048 \\
\hline employed & 0.066 & 0.038 \\
\hline retired/inactive & $0.157^{*}$ & 0.102 \\
\hline$y_{i}$ & $0.047^{*}$ & 0.026 \\
\hline mrti & 0.033 & 0.021 \\
\hline current ltv & -0.012 & 0.016 \\
\hline fixed rate mortgage & -0.012 & 0.034 \\
\hline savings & $0.045^{*}$ & 0.026 \\
\hline credit constrained & 0.015 & 0.029 \\
\hline $\mathrm{N}$ & \multicolumn{2}{|l|}{826} \\
\hline LR chi ${ }^{2}$ & \multicolumn{2}{|l|}{27.45} \\
\hline Prob $>\mathrm{chi}^{2}$ & \multicolumn{2}{|l|}{0.0518} \\
\hline Pseudo $\mathrm{R}^{2}$ & \multicolumn{2}{|l|}{0.0450} \\
\hline
\end{tabular}

Note: ${ }^{* * *}$ Significant at 1 per cent level; ** Significant at 5 per cent level; * Significant at 10 per cent level. Omitted categories for dummy variables are: age 18-34; low education; and unemployed. 
Table 8: Probit model: dependent variable=deleverages, incorporating financial expectations

\begin{tabular}{|c|c|c|}
\hline Variable & Marginal Effect & Std. Error \\
\hline male & -0.011 & 0.024 \\
\hline married & -0.014 & 0.039 \\
\hline HH size & 0.014 & 0.011 \\
\hline age $: 35-44$ & 0.001 & 0.035 \\
\hline age $: 45-54$ & -0.003 & 0.039 \\
\hline age $: 55-64$ & $0.100^{*}$ & 0.068 \\
\hline age $: 65+$ & -0.055 & 0.071 \\
\hline$e d u-m e d$ & 0.062 & 0.044 \\
\hline$e d u-h i g h$ & 0.071 & 0.049 \\
\hline employed & 0.065 & 0.040 \\
\hline retired/inactive & $0.157^{*}$ & 0.103 \\
\hline$y_{i}$ & $0.048^{*}$ & 0.026 \\
\hline mrti & 0.035 & 0.022 \\
\hline current ltv & -0.011 & 0.017 \\
\hline fixed rate mortgage & -0.019 & 0.034 \\
\hline savings & $0.043^{*}$ & 0.026 \\
\hline expect deterioration & $-0.039^{*}$ & 0.023 \\
\hline $\mathrm{N}$ & \multicolumn{2}{|l|}{797} \\
\hline LR chi ${ }^{2}$ & \multicolumn{2}{|l|}{28.64} \\
\hline Prob $>\mathrm{chi}^{2}$ & \multicolumn{2}{|l|}{0.0380} \\
\hline Pseudo $\mathrm{R}^{2}$ & \multicolumn{2}{|l|}{0.0476} \\
\hline
\end{tabular}

Note: ${ }^{* * *}$ Significant at 1 per cent level; ** Significant at 5 per cent level; * Significant at 10 per cent level. Omitted categories for dummy variables are: age 18-34; low education and unemployed. 
Table 9: Implications for consumption - dependent variable: Euro change in consumption

\begin{tabular}{|c|c|c|}
\hline Variable & Coefficient & Std. Error \\
\hline constant & -101.757 & 80.903 \\
\hline male & 1.986 & 28.527 \\
\hline married & 22.721 & 42.536 \\
\hline HH size & $25.003^{*}$ & 13.335 \\
\hline age $: 35-44$ & -5.097 & 41.499 \\
\hline age $: 45-54$ & -11.472 & 43.664 \\
\hline age $: 55-64$ & 63.591 & 54.026 \\
\hline age $: 65+$ & -80.761 & 102.213 \\
\hline$e d u-m e d$ & $90.871^{* *}$ & 41.861 \\
\hline$e d u-h i g h$ & $86.806^{* *}$ & 43.339 \\
\hline employed & 57.550 & 48.351 \\
\hline retired/inactive & 55.668 & 65.481 \\
\hline fixed rate mortgage & 36.652 & 44.195 \\
\hline change in equity & $0.001^{* * *}$ & 0.000 \\
\hline income : fall & $-78.363^{* *}$ & 34.234 \\
\hline deleverage & $-67.864^{*}$ & 40.573 \\
\hline $\mathrm{N}$ & \multicolumn{2}{|c|}{888} \\
\hline$F(15,872)$ & \multicolumn{2}{|c|}{2.31} \\
\hline Prob $>F$ & \multicolumn{2}{|c|}{0.0031} \\
\hline $\mathrm{R}^{2}$ & \multicolumn{2}{|c|}{0.0383} \\
\hline
\end{tabular}

Note: *** Significant at 1 per cent level; ** Significant at 5 per cent level; * Significant at 10 per cent level. 
Table 10: Appendix Table: Loan-Level Data Fields / Information Content

\begin{tabular}{|c|c|c|c|c|c|}
\hline Unit Identifier & Borrower & Property & Loan & Interest Rate & Performance \\
\hline $\begin{array}{l}\text { Bank } \\
\text { Borrower } \\
\text { Property } \\
\text { Loan }\end{array}$ & $\begin{array}{l}\text { Borrower Type } \\
\text { (FTB, BTL, etc.) } \\
\text { Income } \\
\text { Income Verified } \\
\text { Credit Quality }\end{array}$ & $\begin{array}{l}\text { Geographic Location } \\
\text { Property Type } \\
\text { New or Existing } \\
\text { Original Valuation } \\
\text { (and date) } \\
\text { Original LTV } \\
\text { Construction Year }\end{array}$ & $\begin{array}{l}\text { Origination Date } \\
\text { Original Loan Balance } \\
\text { Current Loan Balance } \\
\text { Loan Term } \\
\text { Loan Purpose } \\
\text { Current Repayment } \\
\text { Payment Type } \\
\text { Interest Rate Info. } \\
\text { Performance Info. }\end{array}$ & $\begin{array}{l}\text { Current Interest Rate } \\
\text { Interest Rate Type } \\
\text { Interest Rate Margin } \\
\text { Rate Revision Date }\end{array}$ & $\begin{array}{l}\text { Arrears Balance } \\
\text { (June-2012) } \\
\text { Arrears Balance } \\
\text { for Past } 12 \text { months } \\
\text { Collection Status } \\
\text { Modification / } \\
\text { Forbearance Flag }\end{array}$ \\
\hline
\end{tabular}

Notes: The above fields are not always populated in full. 


\section{Figure 1}

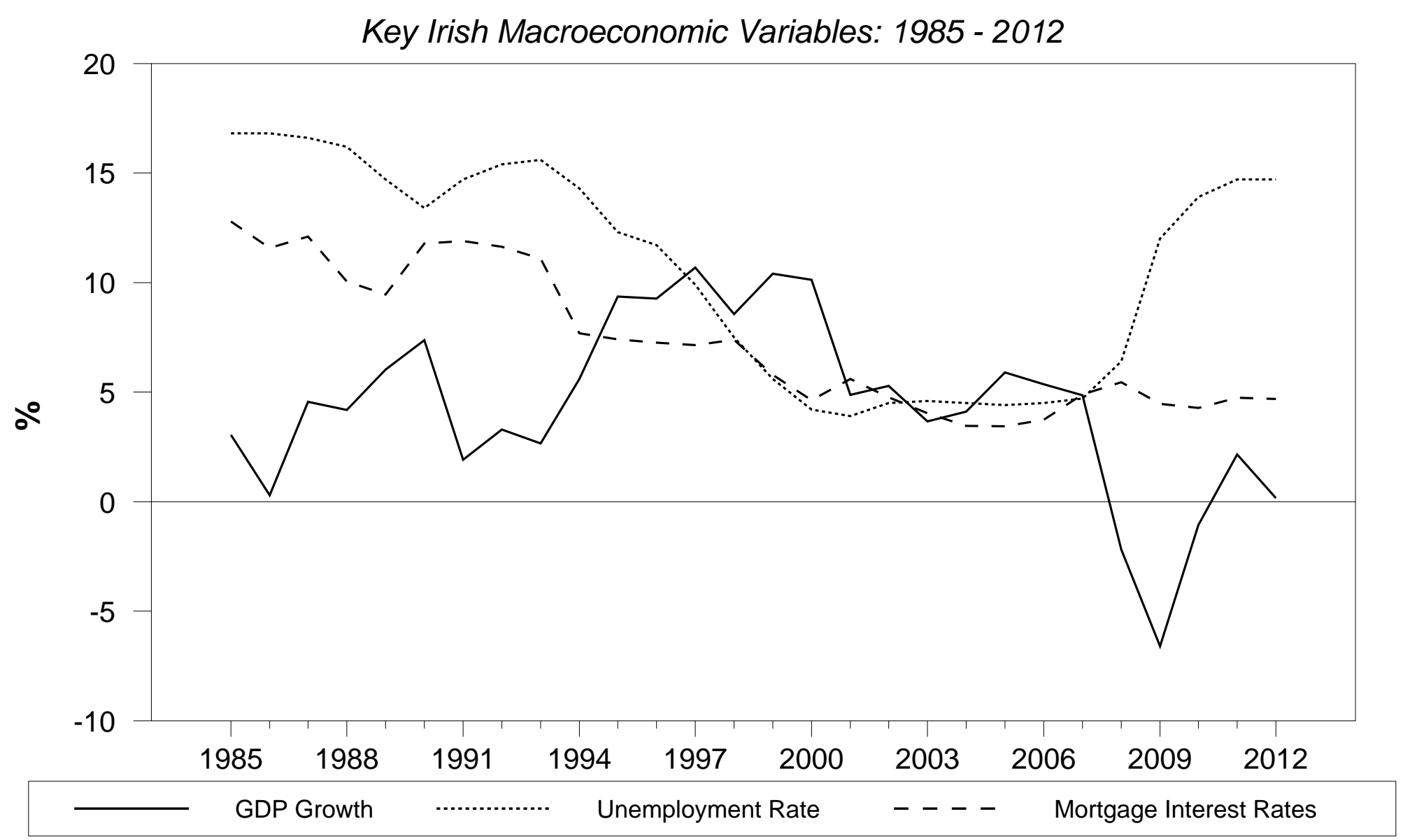




\section{Figure 2}

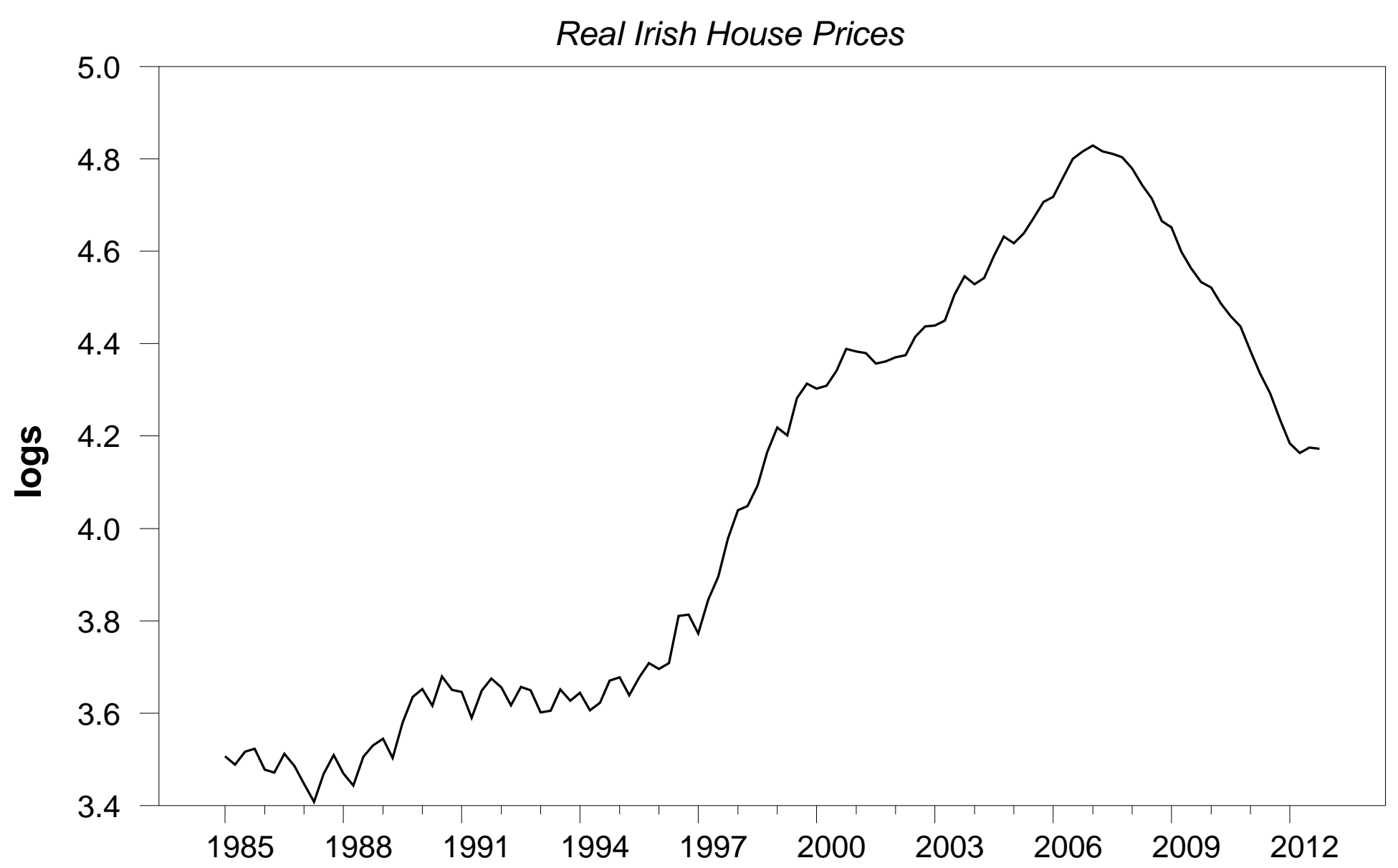




\section{Figure 3}

Funding of Irish Financial Institutions: 2001- 2010
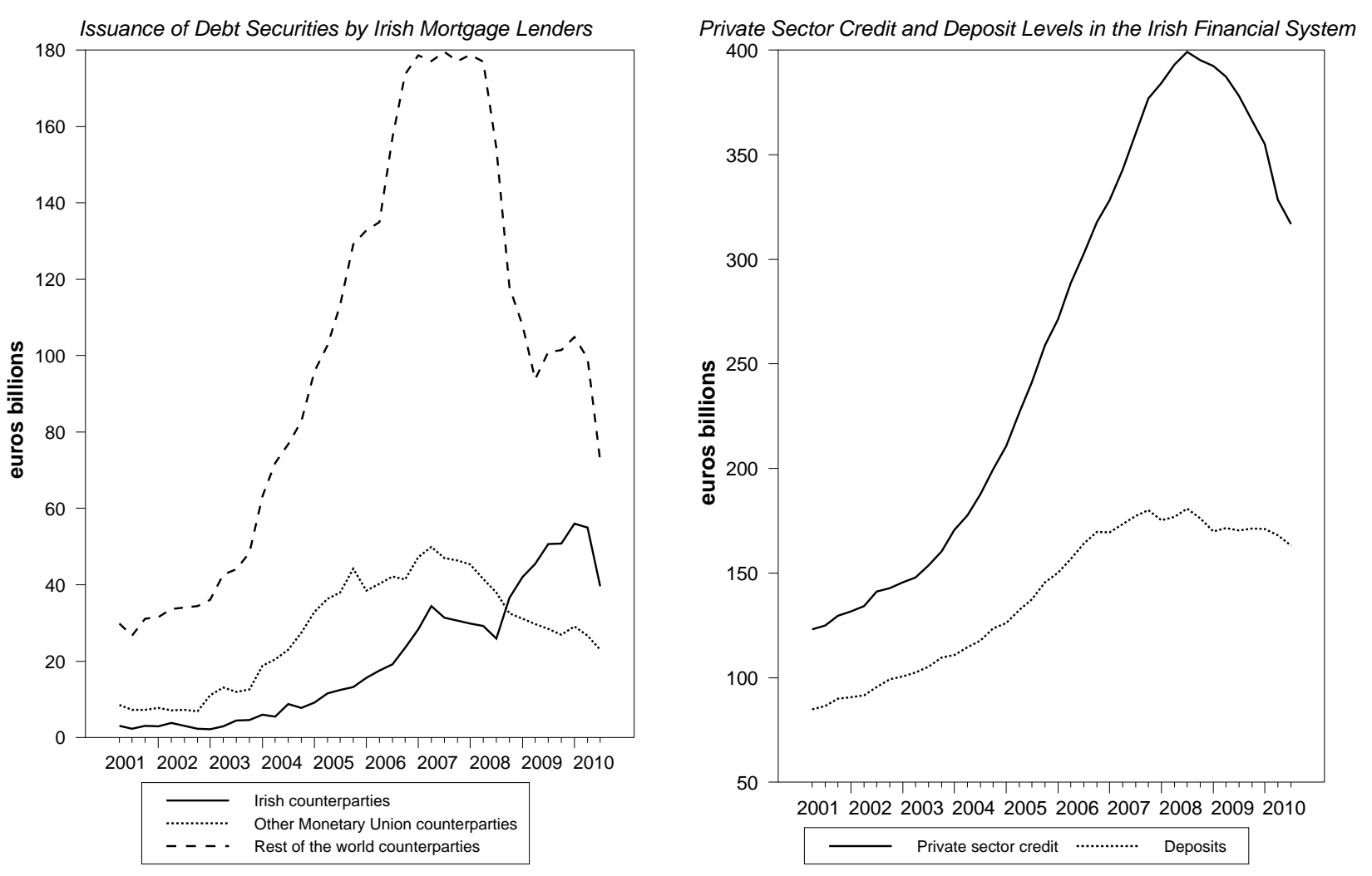


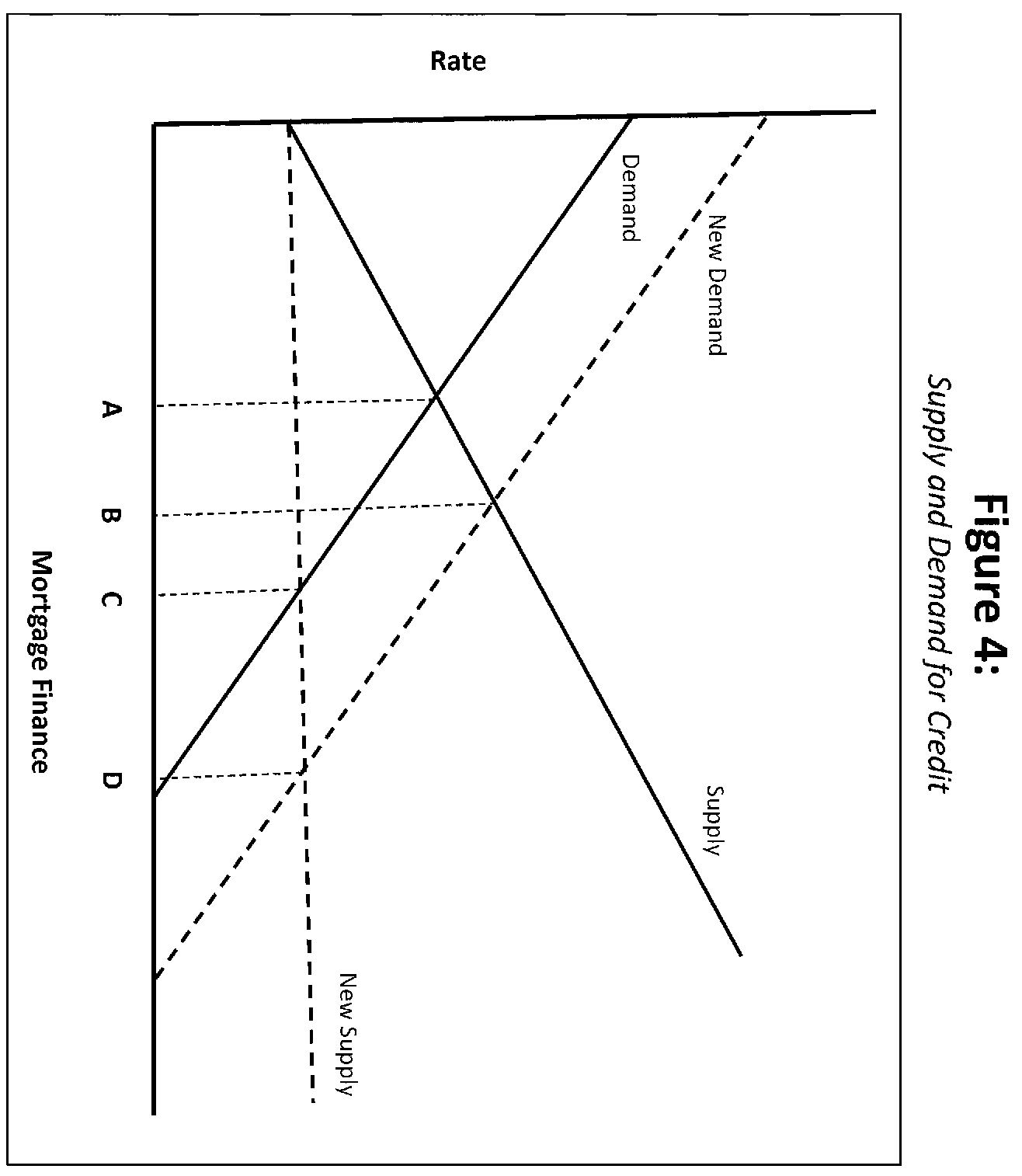


Figure 5

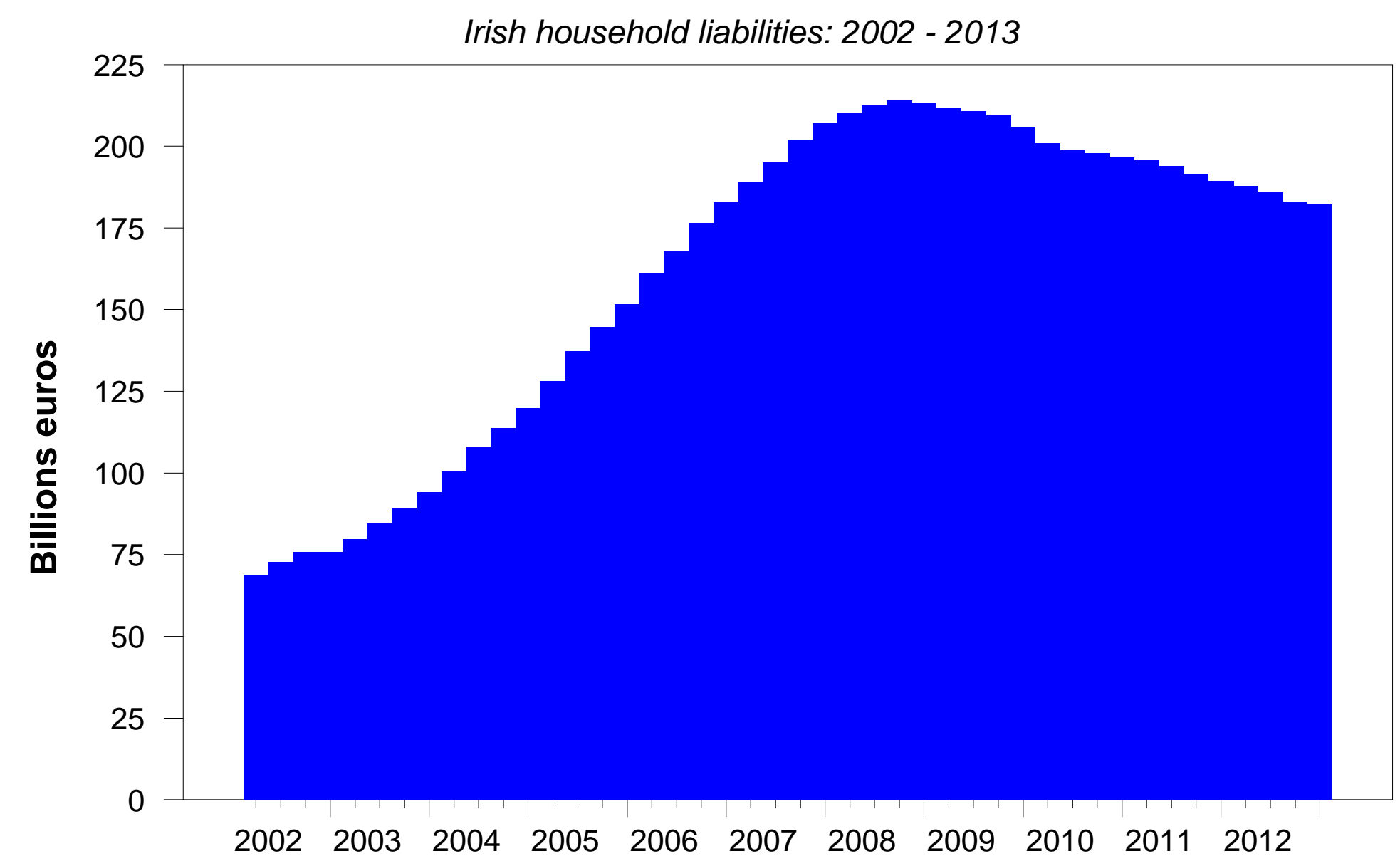




\section{Figure 6}

Irish household leverage ratios: 2002 - 2013

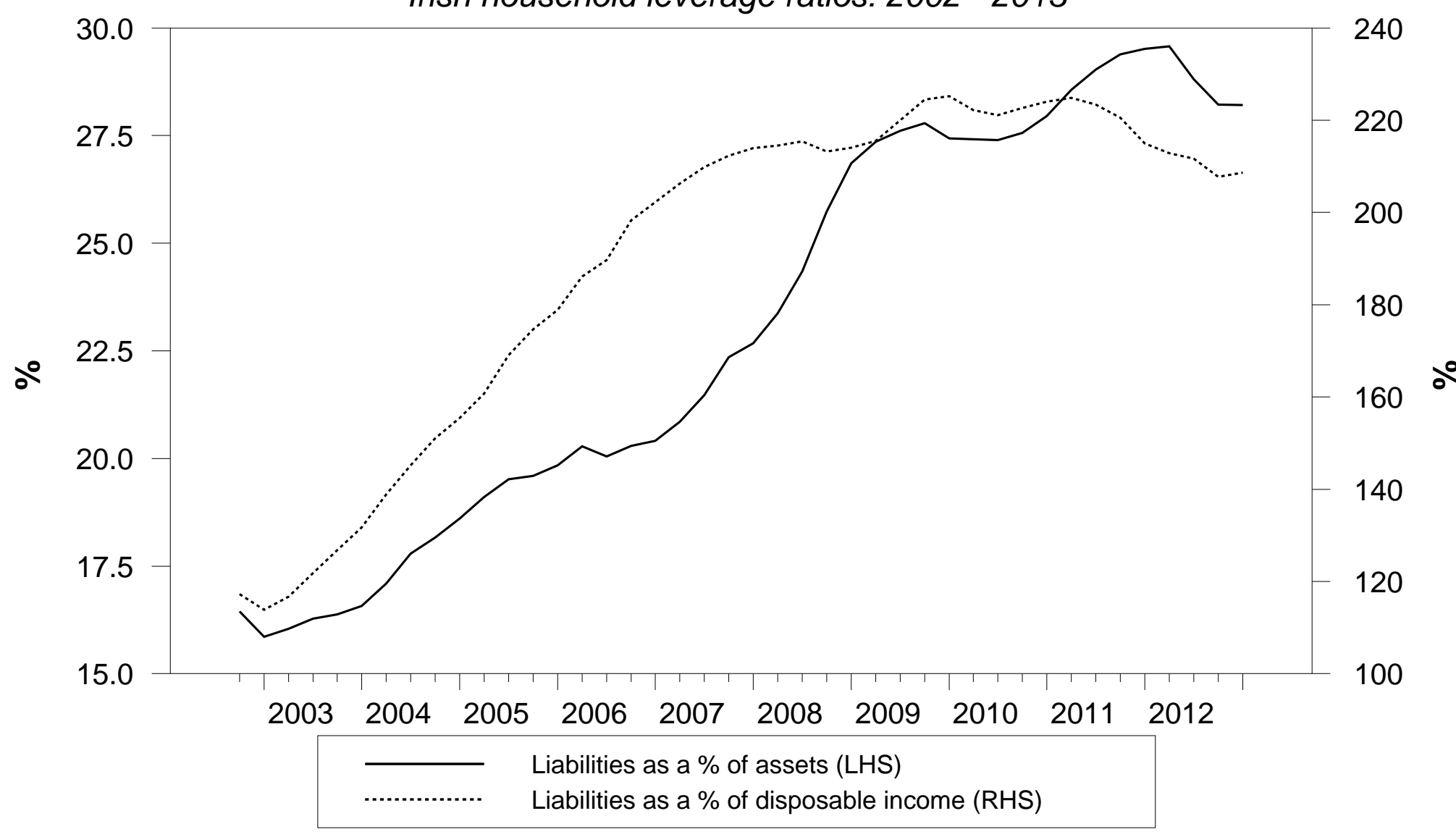


Figure 7

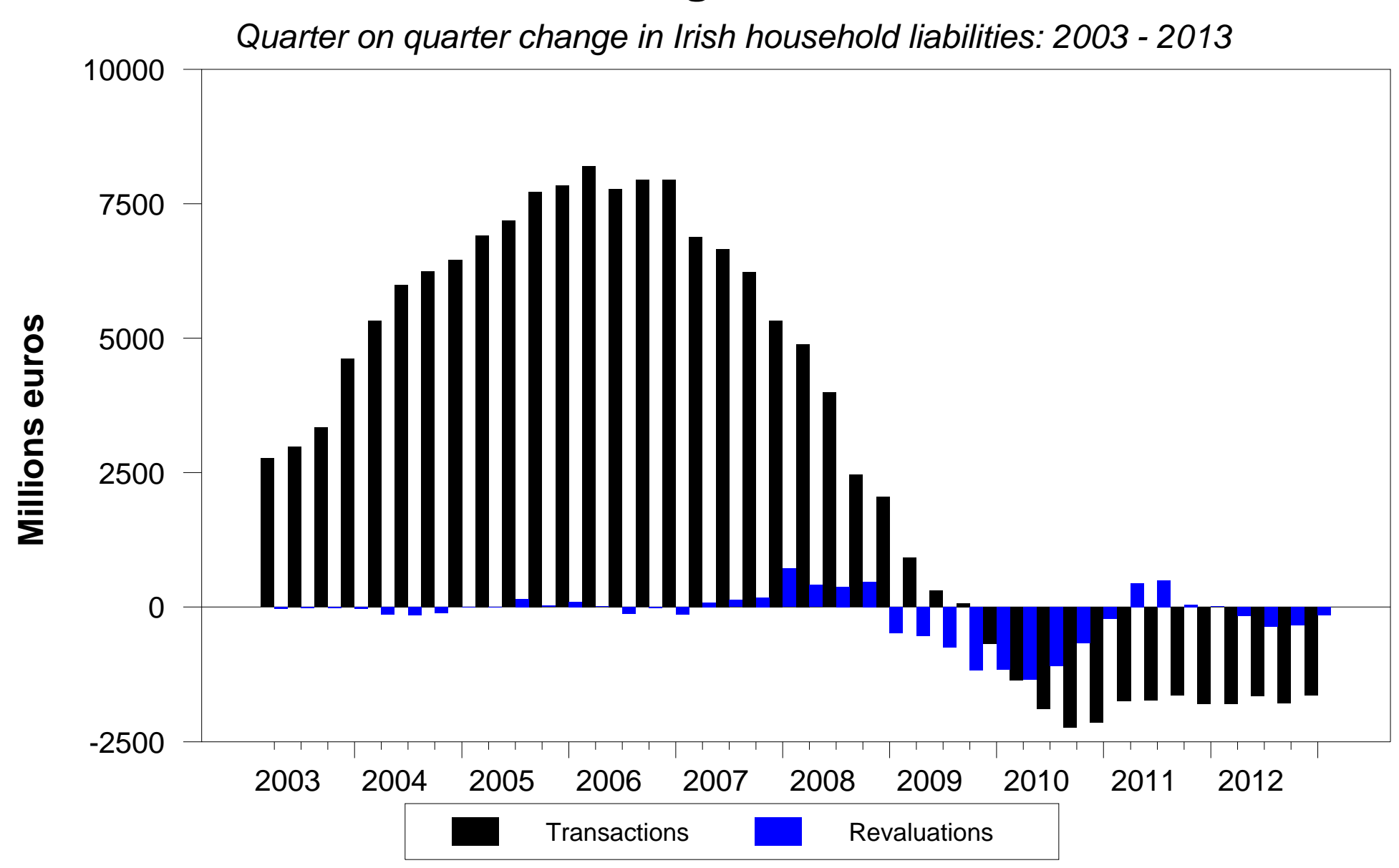


Figure A1: Distribution of Consumption Changes

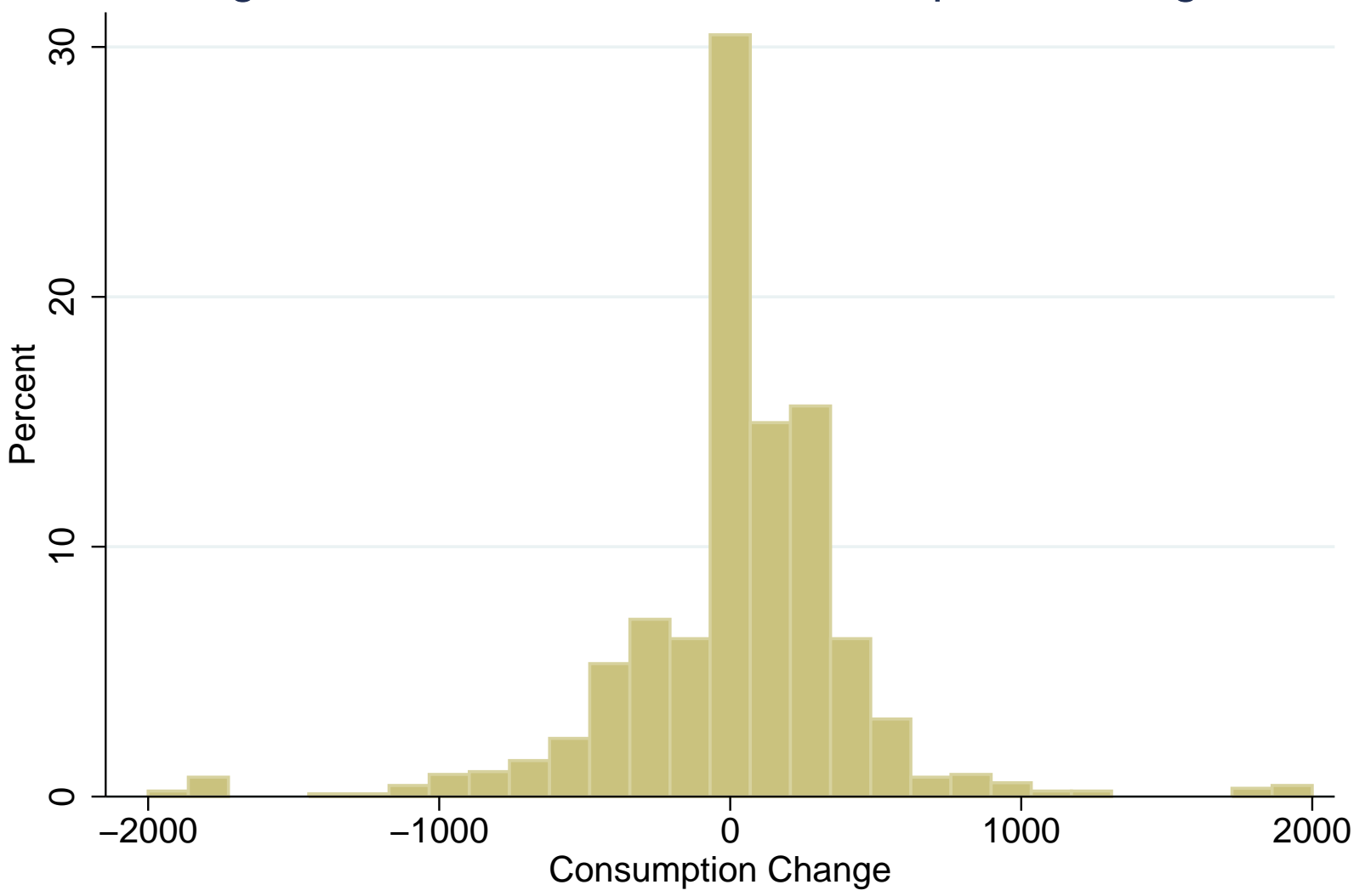

